\title{
Stem cell therapy for idiopathic pulmonary fibrosis: How far are we from the bench to the bedside?
}

\author{
Zheng Wang', Xiaoju Zhang ${ }^{1}$, Yi Kang ${ }^{2}$, Yanli Zeng ${ }^{2}$, Hongmei Liu ${ }^{1}$, Xiaoqian Chen ${ }^{3}$, \\ Lijun $\mathrm{Ma}^{{ }^{*}}$ \\ ${ }^{1}$ Department of Respiratory and Critical Care Medicine, People’s Hospital of Zhengzhou University, Zhengzhou, China \\ ${ }^{2}$ Department of Infectious Disease, People’s Hospital of Zhengzhou University, Zhengzhou, China \\ ${ }^{3}$ Department of Respiratory Medicine, the Second People's Hospital of Anhui Province, Hefei, China \\ Email: malijun0401@163.com
}

Received 19 June 2013; revised 25 July 2013; accepted 5 August 2013

Copyright (C) 2013 Zheng Wang et al. This is an open access article distributed under the Creative Commons Attribution License, which permits unrestricted use, distribution, and reproduction in any medium, provided the original work is properly cited.

\begin{abstract}
Idiopathic pulmonary fibrosis (IPF) is characterized by exuberant apoptosis and inadequate regeneration of lung parenchyma cells. Intratracheal alveolar type II epithelial cell instillation alleviates lung inflammation and fibrosis. Resident lung epithelial stem cells, as well as exogenous mesenchymal stem cells, are capable of differentiating into lung epithelial cells and repair the injured lung. It is thus supposed that, either engraftment of exogenous stem cells, or methods facilitating endogenous lung stem cell proliferation, are promising treatments for IPF, a devastating disease. Arrays of cellular and animal studies have shown the potential of stem cells in alleviating experimental lung fibrosis. Moreover, clinical trials have been launched to investigate the potentials of cell-based therapy in IPF patients. We intend to discuss the newest advances on stem cell therapy in pulmonary fibrosis, particularly the advantages, promises, and possible hurdles to pass from the successes in laboratory experiments to the eventual clinical applications.
\end{abstract}

Keywords: Pulmonary Fibrosis; Mesenchymal Stem Cells; Tissue Engineering; Embryonic Stem Cells; Alveolar Epithelial Cell

\section{INTRODUCTION}

Idiopathic pulmonary fibrosis (IPF) is a cryptogenic but lethal disease. Characterized by exaggerating matrix deposition, lung architecture distortion and honeycombing, IPF results in loss of functional lung volume and gas exchanging capacity. Patients with late-stage IPF mostly

*Corresponding author. die for respiratory failure, accompanying cardiac diseases or lung infections. Whereas the incidence of IPF seems to be low (approximately 2 to 29 cases per 100, 000 individuals), the 5-year survival rate of confirmed IPF patients who receive lung transplantation or not has never exceeded $50 \%$, which is even lower than many malignancies [1,2].

Over the past decade, major accomplishments have been achieved in deciphering, diagnosing and treating IPF, as many new drugs and clinical guidelines have been advanced and utilized in IPF patients [3,4]. Clinical trials have tested a number of single or combination drug therapies, among which the approval of pifernidone in Asia and Europe represents a milestone of overwriting clinical guidelines [5,6]. Frustratingly, the mortality of IPF is still rising regardless of these advances [7]. This dilemma of drug therapies could largely be attributed to the unstoppable, deregulated remodeling process. Neither septa thickening nor alveolar distortion could be reversed with the prescription of any existing drugs including pirfenidone. Thus, pathological cure of IPF is almost impossible currently. Agreements have been made accordingly that the endpoints of clinical trials should no longer be ideally preventing from further disease progression, but more practically, stabilizing lung function and exercise capacities [8].

In spite of these obstacles, stem cell therapy has shed some new lights on the management of IPF. Experts' agreements have been achieved favoring stem cell therapy in chronic airway diseases and pulmonary fibrosis [9-11]. The therapeutic role of mesenchymal stem cells (MSCs) has been implicated in serial processes of lung injury-repair disequilibrium and abnormal remodeling, including experimental lung fibrosis [12-19]. Moreover, clinical trials have been launched to investigate the 
clinical safety and efficacy of MSCs in IPF patients $[20,21]$. It is thus worthwhile to anticipate the possible bedside use of stem cells in pulmonary fibrosis in the future [22-24]. Here we review the up-to-date use of stem cells in experimental pulmonary fibrosis and its potential implications in the clinical settings.

\section{RATIONALES FOR STEM CELL THERAPY IN PULMONARY FIBROSIS}

\subsection{Biological Characteristics of Stem Cells}

According to the International Society for Stem Cell Research (ISSCR), stem cells could be categorized to adult stem cells, embryonic stem cells (ESC) and induced pluripotent stem cells (iPS cells). Due to ethical issues and local legislations, researches and use of embryonic stem cells and iPS cells are unavailable now with human diseases. Therefore, those used for stem cell therapy are predominantly adult stem cells. Adult stem cells include tissue-specific stem cells, mesenchymal stem cells, fetal stem cells and cord blood stem cells. Tissue-specific stem cells reside, and give rise to the mature parenchyma cells within that particular tissue or organ, such as in the lung, skin, muscle, intestine and bone marrow. At least three lung epithelial stem cell populations have been identified [25-28]. Alveolar type II cells and Clara cells also share features with progenitor cells, as they differentiate into alveolar type I cells and airway lining ciliated cells in biological or pathological situations. Stem cell therapies using tissue-specific stem cells have become routine techniques of overcoming hematological malignnancies, skin burns, or corneal diseases. However, the therapeutic role of resident lung stem/progenitor cells is far from clear and warrant further investigations [29,30].

Mesenchymal stem cells (MSC) could be isolated from various tissues including bone marrow, placenta, adipose tissue, and human cord blood. They are able to differentiate into bone, cartilage and fat, and may also aid in the regeneration of tissues [31]. The International Society of Cellular Therapy defined MSC by simultaneously meeting the following three criteria: (1) be adherent to plastic under standard tissue culture conditions; (2) expressing cell surface markers including CD105, CD90, and CD73, and should be negative for other surface markers, including CD45, CD34, CD14, and CD11b; (3) be capable of differentiating into mesenchymal lineages (osteoblasts, chondroblasts and adipocytes) under appropriate in vitro conditions [32]. MSCs are low immunogenic, since they constitutively express low levels of MHC I and II proteins, and are generally lack of T-cell costimulatory molecules such as CD80 and CD86 [33]. Therefore, allogeneic MSC are usually well tolerated by the host $[10,11,33]$. MSCs are able to recruit into the inflamed sites. They modulate the inflammatory process via suppressing $\mathrm{T}$ cell proliferation, secreting an array of antiapoptic, anti-inflammatory and angiogenic factors, and possibly, differentiating into tissue cells [34,35]. After in vitro incubation with specific growth factors, human cord blood-derived mesenchymal stem cells (CBMSCs) are able to express Clara cell secretory protein (CCSP), cystic fibrosis transmembrane conductance regulator (CFTR), surfactant protein $C$, and thyroid transcription factor-1 mRNA, and CCSP and CFTR protein, suggesting the acquisition of alveolar epithelial phenoltype [36]. MSC engraftment ameliorates inflammation and facilitates tissue regeneration, and alleviates fibrosis in models of renal and myocardial injury [37-39]. Additionally, the anti-fibrotic property of MSC is also observed in experimental pulmonary fibrosis.

\subsection{Preclinical Studies of Stem Cells in Pulmonary Fibrosis}

The hallmark histopathological pattern of IPF is usual interstitial pneumonia (UIP) [40]. The exact mechanism underlining IPF/UIP remains unknown. However, the hypothesis has become widely accepted that the convergence of intrinsic genetic predispositions and extrinsic irritants leads to continuous epithelial injury, which further initiates an abnormal fibrosing process that is characterized by activation of fibroblasts and excessive collagen synthesis [41-43]. To date there are no animal models exactly mimicking the pathological process of UIP, but bleomycin-induced lung injury and fibrosis is most relevant and has been widely used [44,45]. Both IPF and bleomycin-induced experimental pulmonary fibrosis are characterized, and possibly induced, by lung epithelial apoptosis $[46,47]$. There are also evidences that lung epithelial stem cells are exhausted and fail to maintain adequate repair in IPF and bleomycin-induced pulmonary fibrosis $[48,49]$.

Accumulating data obtained from animal studies has identified the curing role of stem cells in experimental lung fibrosis. Intravenous injection of bone marrow-derived mesenchymal stem cells (BM-MSCs) significantly reduced bleomycin-induced increase in wet/ dry ratio, degree of neutrophilic infiltration, collagen deposition, and levels of the cytokines and nitric oxide [50]. Another study indicates that intravenous mesenchymal stem cell transfer reduces bleomycin injectioninduced expressions of TGF-beta1, PDGF-A, PDGF-B, and IGF-1 mRNA, and that some MSC engrafts presenting in injured lung tissue are positive for pan-cytokeratin staining, which indicates the differentiation of MSCs into alveolar epithelial cells in vivo [51]. MSCs inhibit the inflammatory responses and cellular injuries, and may differentiate into epithelial-like cells. These capabilities 
are assumed as their mechanisms which reverse experimental pulmonary fibrosis in animals [52]. The anti-inflammatory and anti-fibrotic capabilities are also presented in amnion epithelial cells, placenta-derived cells, umbilical cord mesenchymal stem cells and adiposederived stem cells (ADSCs) [53-59]. Interestingly, ESC engraftment also ameliorates experimental pulmonary fibrosis, although clinical research using ESCs is forbidden at the current time [60,61].

\section{CLINICAL INVESTIGATIONS OF STEM CELLS IN IPF}

Former clinical studies have demonstrated the efficacy and safety of a commercially available MSC product (prochymal, Osiris Therapeutics Inc., Columbia, MA) in patients with ischemic cardiomyopathy $[62,63]$. A recently published trial assessed the safety and potential efficacy of intravenous infusion of MSCs (108 cells per infusion, once per month for consecutively 4 months) on patients with moderate to severe chronic obstructive pulmonary disease (COPD). Sixty-two patients were randomized to the MSC group or control group, all of whom completed the infusion protocol, and 74\% completed the 2-year follow-up. No deaths, serious adverse events or infusion-related toxicities were closely related to MSC administration. MSC infusion was not correlated with disease exacerbations or increase of side effects. There were no significant differences in lung function parameters or quality-of-life indicators. MSC infusion results in an early, significant decrease in levels of circulating C-reactive protein who had elevated CRP levels at study entry [64].

There are no published trials about the use of stem cells in IPF patients. Nonetheless, a few studies might provide some evidences in the next future. Tzouvelekis et al (2011) have launched a trial to evaluate the safety, lung toxicity, patients' tolerability and antiinflammatory activity of endobronchial autologous infusion of ADSCs in IPF patients [20]. Compared with MSCs, ADSCs also have shown migratory, differentiative and fibro-sisreparative capacities, which are more easily isolated and enriched from adipose tissue, and are able to proliferate ex vivo. In this ongoing prospective, single-centered, nonrandomized clinical trial, well-selected patients would be randomized to the ADSC engraftment group and the control group. ADSCs are isolated via lipoaspiration autologously. Platelet rich plasma is prepared from blood simultaneously. ADSCs are activated by firstly coculture with platelet rich plasma and then by low-level laser irradiation, and are labeled with ${ }^{99 \mathrm{~m}}$ Tc-ceretec thereafter. ADSC engraftment group would receive endobronchial infusion of ADSCs suspended in $10 \mathrm{ml}$ aliquot (low treatment level: $0.5 \times 10^{6}$ cells $/ \mathrm{kg}$; high treatment level:
$0.5 \times 10^{6}$ cells $/ \mathrm{kg}$ ) in both lower lobes, monthly for consecutive three months. Primary endpoints are safety and undesirable side effects, which include contaminations, neoplasia, fever, ectopic tissue formation, disease exacerbation, allergy, toxicity, and so on. Secondary endpoints denoting efficacy, are classified as clinical (arterial blood gases, dyspnea scales, quality of life), functional (6minute walk test and lung function parameters) and radiological alterations (evaluated by high-resolution computed tomography). The safety of the procedures is partially witnessed by a preceding, small-scare preliminary trial which aims to visualize the ${ }^{99 \mathrm{~m}}$ Tc-ceretec-labeled ADSCs in IPF patients $(n=4)$ [20]. This clinical research will disclose the safety and efficacy of endobronchial infusion of autologous ADSCs in IPF patients.

\section{CHALLENGES AND FUTURE DIRECTIONS FOR THE BENCH-TO-BEDSIDE TRANSLATION}

\subsection{How to Evaluate the Efficacy}

Idiopathic interstitial pneumonias, including IPF, have been defined as three-facetted diseases manifesting different clinical, radiological and pathological features. Since pathological resolution is unnecessarily reached in almost all clinical trials about IPF, focus should be spent more on radiological, especially, functional and clinical improvements. In the new era of translational medicine, the endpoints of clinical trials on IPF are switching from preventing from further disease progression to stabilizing lung function and exercise capacities [8,65]. More emphasis should be drawn on the functional status of patients, as well as the development and usage of biomarkers, instead of focusing in the reversal of the pathological alterations [66].

Importantly also, a great gap always exists between experimental pulmonary fibrosis and human IPF. Bleomycin-induced lung injury is characterized by marked acute pulmonary inflammation lasting for about 10 days, and subsequent fibrosis develops in 2 to 3 weeks but seldom progresses thereafter. In contrast, the process of lung injury and repair is consistent, and lung fibrosis is chronically and desperately progressing for months or years in human IPF [67,68]. There emerge arguments that bleomycin-induced experimental pulmonary fibrosis does not necessarily represent similar changes in IPF [69]. In this viewpoint, the success of stem cell engraftment in animal models of pulmonary fibrosis does not necessarily warrant its therapeutic role in IPF patients [70]. Another concern arises that, a large proportion of IPF patients are diagnosed at the middle or late stage of disease, whose lung architectures are distorted and full of fibrosis and honeycombing. On the other hand though, 
MSC engraftment does not sufficiently attenuate bleomycin-induced lung fibrosis at the late stage (eg. 21days after bleomycin exposure, unpublished data). The preliminary study of MSCs in COPD patients shows their anti-inflammatory efficacy but no improvements in disease exacerbations, lung function parameters or health-related quality-of-life. Taken these together, we might not be too optimistic about the forthcoming era of stem cell therapy in IPF, if it surely would come.

\subsection{Safety and Ethical Concerns}

A major controversy about stem cell therapy focuses on its potential adverse effects on human body, such as carcinogenesis and immune intolerance. To date, a few large randomized, controlled trials using commercially-available MSCs intravenously (e.g. 107 cells per each injection) have not shown any excessive and adverse effects with respect to human bodies [62,63]. However, there is little knowledge about the safety of MSC engraftment in humans with a higher dose, intratracheally or through a pulmonary artery catheter. MSC engraftment could aggravate collagen-induced arthritis by activating IL-6 production and Th17 differentiation [52]. Therefore, we must always keep alert of these possible side effects in clinical trials or clinical uses. The production, collection, culture and growth, genetic modification, transportation and final usage of stem cells are obliged to be kept in accordance with international ethical guidelines and regional laws [71].

\subsection{Maximizing the Effects of Stem Cell Engraftment}

There are many issues to be taken account prior to the use of stem cells to treat lung diseases. Before it becomes a THERAPY for patients and no longer a METHOD for mice, stem cell engraftment should be scrutinized for indications and contraindications. Other major considerations include the purpose of the engraftment, which cell to engraft and how to perform it, the potency of engraftment, will the engraft form tumors, will cells be rejected, could cells cause undesirable damage, should cell be genetically modified as a gene vehicle, and so on [72]. For example, either intravenous or intratracheal administration of stem cells could diminish bleomy-cininduced pulmonary fibrosis. The optimal giving route should be investigated and fixed by carefully-designed comparison studies. It is recommended that the dosing parameters and giving route, the survival, growth and differentiation of exogenous stem cells be optimized in vivo by clinical trials, so as to offer patients with therapeutic benefits at relatively little risk [73]. These considerations are also important for conceiving clinical trials, in case that there would be increasing number of clinical studies on this issue, regardless of the final results of the preliminary studies.

Except for transplanted MSCs, there are also evidences that lung resident stem/progenitor cells contribute to lung repair and regeneration $[10,11,29,30]$. Chemicals, cytokines and signaling pathways such as ATRA, KGF, Wnt/beta-catenin signaling pathway regulates the in vivo and in vitro differentiation of stem cells [74-77]. Further studies are necessitated to activate the regenerative potential of endogenous lung stem cells. However, this aspect of stem cell manipulation has always been neglected.

Grove et al (2002) have shown that BM-MSCs are easily manipulated with endogenous genes and form lung epithelia in vivo [78]. The authors declare that using bone marrow stem cells as a vector for gene delivery has several advantages, including their accessibility, their easily homing to the inflamed lung tissue via intratracheal injection or by migration after intravenous injecttion, the feasibility to be manipulated in vitro, and their low immunogenicity and high host compatibility [78]. MSCs carrying CFTR genes do well differentiate into lung epithelial cells and produce epithelial marker such as surface proteins [79]. A more recent study demonstrated that engraftment of BM-MSCs expressing keratinocyte growth factor (KGF) gene protects from bleomycin-induced pulmonary fibrosis in vivo [80]. It is no longer unimaginable that genetically modified MSCs, would act well as therapeutic gene vehicles targeting key fibrotic signals such as TGF-beta1, Wnt/beta-catenin or Notch [81].

Lung tissue engineering has been available, since stem cells could be adequately conditioned to differentiate into both lung epithelial cells and matrix cells. By isolation, culture and stimulation, Macchiarini et al (2008) successfully used a patient's epithelial cells and MSC-derived chondrocytes to generate a bioengineered trachea, which were then transplanted and substituted the previously ruined trachea [82]. The xenograft functioned sufficiently as the conducting airway without any need for intake of immunosuppressants. There are also observations that fetal lung cells imbedded in matrigel sponges are able to form the branching airway structures [83,84]. However, as compared with the trachea, the lung is a far more delicate system that consists of 16 grades of bronchi, numerous blood vessels and capillaries and more than 40 cell types. In this scenario, we are technically challenged by bioengineering of this sophisticated, three-dimensional architecture [85]. It demands revolutionary advances in stem cell researches, biomaterials, developmental biology, biophysics and biological chemistry, to realize the final success of creating a whole lung with stem cells. This is indeed a long way to go. 


\section{CONCLUSION}

In conclusion, IPF is still a relentless disease with few effective therapies. Pifernidone slows, but does not reverse the progressive step of IPF. In another respect, stem cells possess the biological properties of recruiting, paracrine, immunosuppressive and differentiation in the lung. Engraftment of various kinds of stem cells alleviates or prevents from lung fibrosis in animal models. Clinical trials are also on the way to explore the safety and therapeutic significance of mesenchymal stem cells in IPF patients. The bench-to-bedside translation has just begun. It is worthy to anticipate that these trials may open a new gate towards curing of IPF.

\section{REFERENCES}

[1] Chen, X., Zhang, X., Li, X. and Wang, Z. (2013) Who and what should we rely on in early diagnosis of IPF? European Respiratory Journal, 41, 249-250. doi:10.1183/09031936.00142012

[2] Nathan, S.D., Shlobin, O.A., Weir, N., Ahmad, S., Kaldjob, J.M., Battle, E., et al. (2011) Long-term course and prognosis of idiopathic pulmonary fibrosis in the new millennium. Chest, 140, 221-229. doi:10.1378/chest.10-2572

[3] Raghu, G., Collard, H.R., Egan, J.J., Martinez, F.J., Behr, J., Brown, K.K., et al. (2011) An Official ATS/ERS/JRS/ ALAT statement: Idiopathic pulmonary fibrosis: Evidence-based guidelines for diagnosis and management. American Journal of Respiratory and Critical Care Medicine, 183, 788-824. doi:10.1164/rccm.2009-040GL

[4] Behr, J. (2013) Evidence-based treatment strategies in idiopathic pulmonary fibrosis. European Respiratory Review, 22, 163-168. doi:10.1183/09059180.00001013

[5] Spagnolo, P., Del Giovane, C., Luppi, F., Cerri, S., Balduzzi, S., Walters, E.H., et al. (2010) Non-steroid agents for idiopathic pulmonary fibrosis. Cochrane Database of Systematic Reviews, 9, Article ID: CD003134. doi:10.1002/14651858.CD003134.pub2

[6] Nobel, P.W., Abera, C., Bradford, W.Z., Costabel, U., Glassberg, M.K., Kardatzke, D., et al. (2011) Pifernidone in patients with idiopathic pulmonary fibrosis (CAPACITY): Two randomised trials. Lancet, 377, 1760-1769. doi:10.1016/S0140-6736(11)60405-4

[7] Navaratnam, V., Fleming, K.M., West, J., Smith, C.J., Jenkins, R.G., Fogarty, A., et al. (2011) The rising incidence of idiopathic pulmonary fibrosis in the UK. Thorax, 66, 462-467. doi:10.1136/thx.2010.148031

[8] Adamali, H.I. and Maher, T.M. (2012) Current and novel drug therapies for idiopathic pulmonary fibrosis. Drug Design, Development and Therapy, 6, 261-272. doi:10.2147/DDDT.S29928

[9] Weiss, D.J., Berberich, M.A., Borok, Z., Stripp, B.R., Gail, D.B., Kolls, J.K., et al. (2006) Adult stem cells, lung biology, and lung disease. NHLBI/Cystic Fibrosis Foundation Workshop. Proceedings of the American Thoracic Society, 3, 193-207.
doi:10.1513/pats.200601-013MS

[10] Weiss, D.J., Kolls, J.K., Ortiz, L.A., Panoskaltsis-Mortari, A. and Prockop, D.J. (2008) Stem cells and cell therapies in lung biology and lung diseases. Proceedings of the American Thoracic Society, 5, 637-667. doi:10.1513/pats.200804-037DW

[11] Weiss, D.J., Bertoncello, I., Borok, Z., Kim, C., Panoskaltsis-Mortari, A., Reynolds, S., et al. (2011) Stem cells and cell therapies in lung biology and lung diseases. Proceedings of the American Thoracic Society, 8, 223-272. doi:10.1513/pats.201012-071DW

[12] Matthay, M.A., Thompson, B.T., Read, E.J., McKenna, D.H. Jr., Liu, K.D., Calfee, C.S., et al. (2010) Therapeutic potential of mesenchymal stem cells for severe acute lung injury. Chest, 138, 965-972. doi:10.1378/chest.10-0518

[13] Lee, J.W., Fang, X., Gupta, N., Serikov, V. and Matthay, M.A. (2009) Allogeneic human mesenchymal stem cells for treatment of E. coli endotoxin-induced acute lung injury in the ex vivo perfused human lung. Proceedings of the National Academy of Sciences of USA, 106, 1635716362. doi:10.1073/pnas.0907996106

[14] Ishizawa, K., Kubo, H., Yamada, M. Kobayashi, S., Numasaki, M., Ueda, S., et al. (2004) Bone marrow derived cells contribute to lung regeneration after elastase-induced pulmonary emphysema. FEBS Letters, 556, 249-252. doi:10.1016/S0014-5793(03)01399-1

[15] Zhen, G., Liu, H., Gu, N., Zhang, H., Xu, Y. and Zhang, Z. (2008) Mesenchymal stem cells transplantation protects against rat pulmonary emphysema. Frontiers in Bioscience, 13, 3415-3422. doi:10.2741/2936

[16] Schweitzer, K.S., Johnstone, B.H., Garrison, J., Rush, N.I., Cooper, S., Traktuev, D.O., et al. (2011) Adipose stem cell treatment in mice attenuates lung and systemic injury induced by cigarette smoking. American Journal of Respiratory and Critical Care Medicine, 183, 215-225. doi:10.1164/rccm.201001-01260C

[17] Sueblinvong, V., Loi, R., Eisenhauer, P.L., Bernstein, I.M., Suratt, B.T., Spees, J.L., et al. (2008) Derivation of lung epithelium from human cord blood-derived mesenchymal stem cells. American Journal of Respiratory and Critical Care Medicine, 177, 701-711. doi:10.1164/rccm.200706-8590C

[18] Bonfield, T.L., Koloze, M., Lennon, D.P., Zuchowski, B., Yang, S.E. and Caplan, A.I. (2010) Human mesenchymal stem cells suppress chronic airway inflammation in the murine ovalbumin asthma model. American Journal of Physiology-Lung Cellular and Molecular Physiology, 299, L760-L770. doi:10.1152/ajplung.00182.2009

[19] Ortiz, L.Z., Gambelli, F., McBride, C., Gaupp, D., Baddoo, M., Kaminski, N., et al. (2003) Mesenchymal stem cell engraftment in lung is enhanced in response to bleomycin exposure and ameliorates its fibrotic effects. Proceedings of the National Academy of Sciences of USA, 100, 8407-8411. doi:10.1073/pnas.1432929100

[20] Tzouvelekis, A., Koliakos, G., Ntolios, P., Baira, I., Bouros, E., Oikonomou, A., et al. (2011) Stem cell therapy for idiopathic pulmonary fibrosis: a protocol proposal. Journal of Translational Medicine, 9, 182. 
doi:10.1186/1479-5876-9-182

[21] Tzouvelekis, A., Paspaliaris, V., Koliakos, G., Ntolios, P., Oikonomou, A., Froudarakis, M., et al. (2011) A prospective, non randomized, clinical trial to study the safety and efficacy of the endobronchial autologous infusion of adipose-derived mesenchymal stem cells (ADMSCs) in patients with idiopathic pulmonary fibrosis (IPF). European Respiratory Journal, 176, 3s.

[22] Gharaee-Kermani, M., Gyetko, M.R., Hu, B. and Phan, S.H. (2007) New insights into the pathogenesis and treatment of idiopathic pulmonary fibrosis: A potential role for stem cells in the lung parenchyma and implications for therapy. Pharmaceutical Research, 24, 819-841. doi:10.1007/s11095-006-9216-X

[23] Tzouvelekis, A., Antoniadis, A. and Bouros, D. (2011) Stem cell therapy in pulmonary fibrosis. Current Opinion in Pulmonary Medicine, 17, 368-373. doi:10.1097/MCP.0b013e328348744f

[24] Toonkel, R.L., Hare, J.M., Matthay, M.A. and Glassberg, M.K. Mesenchymal stem cells and idiopathic pulmonary fibrosis: potential for clinical testing. (2013) American Journal of Respiratory and Critical Care Medicine, 188, 133-140. doi:10.1164/rccm.201207-1204PP

[25] Giangreco, A., Reynolds, S.D. and Stripp, B.R. (2002) Terminal bronchioles harbor a unique airway stem cell population that localizes to the bronchoalveolar duct junction. American Journal of Pathology, 161, 173-182. doi:10.1016/S0002-9440(10)64169-7

[26] Hong, K.U., Reynolds, S.D., Watkins, S., Fuchs, E. and Stripp, B.R. (2004) Basal cells are a multipotent progenytor capable of renewing the bronchial epithelium. American Journal of Pathology, 164, 577-588. doi:10.1016/S0002-9440(10)63147-1

[27] Kim, C.F., Jackson, E.L., Woolfenden, A.E., et al. (2005) Identification of bronchioalveolar stem cells in normal lung and lung cancer. Cell, 121, 823-835. doi:10.1016/j.cell.2005.03.032

[28] Kajstura, J., Rota, M., Hall, S.R., Hosoda, T., D’Amario, D., Sanada, F., et al. (2011) Evidence for human lung stem cells. The New England Journal of Medicine, 364, 1795-1806. doi:10.1056/NEJMoa1101324

[29] Olsson, F., Denham, M., Cole, T.J., Hooper, S.B. and Mollard, R. (2007) Deriving respiratory cell types from stem cells. Current Stem Cell Research \& Therapy, 2, 197-208. doi:10.2174/157488807781696203

[30] Gomperts, B.N. and Strieter, R.M. (2007) Stem cells and chronic lung disease. Annual Review of Medicine, 58, 285-298. doi:10.1146/annurev.med.58.081905.134954

[31] Krause, D.S., Theise, N.D., Collector, M.I., Henegariu, O., Hwang, S., Gardner, R., et al. (2001) Multi-organ, multi-lineage engraftment by a single bone marrow-derived stem cell. Cell, 105, 369-377. doi:10.1016/S0092-8674(01)00328-2

[32] Dominici, M., Le Blanc, K., Mueller, I., Slaper-Cortenbach, I., Marini, F., Krause, D., et al. (2006) Minimal criteria for defining multipotent mesenchymal stromal cells. The International Society for Cellular Therapy position statement. Cytotherapy, 8, 315-317. doi:10.1080/14653240600855905
[33] Le Blanc, K., Tammik, C., Rosendahl, K., Zetterberg, E. and Ringdén, O. (2003) HLA expression and immunologic properties of differentiated and undifferentiated mesenchymal stem cells. Experimental Hematology, 31, 890-896. doi:10.1016/S0301-472X(03)00110-3

[34] Brody, A.R., Salazar, K.D. and Lankford, S.M. (2010) Mesenchymal stem cells modulating lung injury. Proceedings of the American Thoracic Society, 7, 130-133. doi:10.1513/pats.200908-091RM

[35] Garcia-Gomez, I., Elvira, G., Zapata, G., Lamana, M.L., Ramirez, M., Castro, J.G., et al. (2010) Mesenchymal stem cells: Biological properties and clinical applications. Expert Opinion on Biological Therapy, 10, 1453-1468. doi:10.1517/14712598.2010.519333

[36] Sueblinvong, V., Loi, R., Eisenhauer, P.L., Bernstein, I.M., Suratt, B.T., Spees, J.L., et al. (2008) Derivation of lung epithelium from human cord blood-derived mesenchymal stem cells. American Journal of Respiratory and Critical Care Medicine, 177, 701-711. doi:10.1164/rccm.200706-8590C

[37] Newman, R.E., Yoo, D., LeRoux, M.A. and Danilkovitch-Miagkova, A. (2009) Treatment of inflammatory diseases with mesenchymal stem cells. Inflammation \& Allergy-Drug Targets, 8, 110-123. doi:10.2174/187152809788462635

[38] Togel, F., Hu, Z., Weiss, K., Isaac, J., Lange, C. and Westenfelder, C. (2005) Administered mesenchymal stem cells protect against ischemic acute renal failure through differentiation-independent mechanisms. American Journal of Physiology—Renal Physiology, 289, F31-F42. doi:10.1152/ajprenal.00007.2005

[39] Miyahara, Y., Nagaya, N., Kataoka, M., Yanagawa, B., Tanaka, K., Hao, H., et al. (2006) Monolayered mesenchymal stem cells repair scarred myocardium after myocardial infarction. Nature Medicine, 12, 459-465. doi:10.1038/nm1391

[40] American Thoracic Society, European Respiratory Society (2002) American thoracic society/European respiretory society international multidisciplinary consensus classification of the idiopathic interstitial pneumonias. American Journal of Respiratory and Critical Care Medicine, 165, 277-304. doi:10.1164/ajrccm.165.2.ats01

[41] Selman, M., King Jr., T.E. and Pardo, A. (2001) Idiopathic pulmonary fibrosis: Prevailing and evolving hypotheses about its pathogenesis and implications for therapy. Annals of Internal Medicine, 134, 136-151. doi:10.7326/0003-4819-134-2-200101160-00015

[42] Kalluri, R. and Neilson, E.G. (2003) Epithelial-mesenchymal transition and its implications for fibrosis. Journal of Clinical Investigation, 112, 1776-1784. doi:10.1172/JCI200320530

[43] Selman, M., Pardo, A. and Kaminshi, N. (2008) Idiopathic pulmonary fibrosis: Aberrant recapitulation of developmental programs? PLoS Medicine, 5, e62. doi:10.1371/journal.pmed.0050062

[44] Wuyts, W.A., Agostini, C., Antoniou, K.M., Bouros, D., Chambers, R.C., Cottin, V., et al. (2013) The pathogenesis of pulmonary fibrosis: A moving target. European Respiratory Journal, 41, 1207-1218. 
doi:10.1183/09031936.00073012

[45] Moore, B.B. and Hogaboam, C.M. (2008) Murine models of pulmonary fibrosis. American Journal of PhysiologyLung Cellular and Molecular Physiology, 294, L152L160. doi:10.1152/ajplung.00313.2007

[46] Uhal, B.D. (2008) The role of apoptosis in pulmonary fibrosis. European Respiratory Review, 17, 138-144. doi:10.1183/09059180.00010906

[47] Sisson, T.H., Mendez, M., Choi, K., Subbotina, N., Courey, A., Cunningham, A., et al. (2010) Targeted injury of type II alveolar epithelial cells induces pulmonary fibrosis. American Journal of Respiratory and Critical Care Medicine, 181, 254-263. doi:10.1164/rccm.200810-16150C

[48] Chilosi, M., Doglioni, C., Murer, B. and Poletti, V. (2010) Epithelial stem cell exhaustion in the pathogenesis of idiopathic pulmonary fibrosis. Sarcoidosis, Vasculitis and Diffuse Lung Diseases, 27, 7-18.

[49] Jun, D., Garat, C., West, J., Thorn, N., Chow, K., Cleaver, T., et al. (2011) The pathology of bleomycin-induced fibrosis is associated with loss of resident lung mesenchymal stem cells that regulate effector T-cell proliferation. Stem Cell, 29, 725-735. doi:10.1002/stem.604

[50] Lee, S.H., Jang, A.S., Kim, Y.E., Cha, J.Y., Kim, T.H., Jung, S., et al. (2010) Modulation of cytokine and nitric oxide by mesenchymal stem cell transfer in lung injury/ fibrosis. Respiratory Research, 8, 16.

doi:10.1186/1465-9921-11-16

[51] Zhao, F., Zhang, Y.F., Liu, Y.G., Zhou, J.J., Li, Z.K., Wu, C.G., et al. (2008) Therapeutic effects of bone marrowderived mesenchymal stem cells engraftment on bleomycin-induced lung injury in rats. Transplantation Proceedings, 40, 1700-1705. doi:10.1016/j.transproceed.2008.01.080

[52] Wang, S., Qu, X. and Zhao, C. (2012) Clinical applications of mesenchymal stem cells. Journal of Hematology \& Oncology, 5, 19. doi:10.1186/1756-8722-5-19

[53] Kotton, D.N., Ma, B.Y., Cardoso, W.V., Sanderson, E.A., Summer, R.S., Williams, M.C., et al. (2001) Bone marrow-derived cells as progenitors of lung alveolar epithelium. Development, 128, 5181-5188.

[54] Spees, J.L., Pociask, D.A., Sullivan, D.E., Whitney, M.J., Lasky, J.A., Prockop, D.J., et al. (2007) Engraftment of bone marrow progenitor cells in a rat model of asbestosinduced pulmonary fibrosis. American Journal of Respiratory and Critical Care Medicine, 176, 385-394. doi: 10.1164/rccm.200607-1004OC

[55] Kumamoto, M., Nishiwaki, T., Matsuo, N., Kimura, H. and Matsushima, K. (2009) Minimally cultured bone marrow mesenchymal stem cells ameliorate fibrotic lung injury. European Respiratory Journal, 34, 740-748. doi:10.1183/09031936.00128508

[56] Moodley, Y., Ilancheran, S., Samuel, C., Vaghjiani, V., Atienza, D., Williams, E.D., et al. (2010) Human amnion epithelial cell transplantation abrogates lung fibrosis and augments repair. American Journal of Respiratory and Critical Care Medicine, 182, 643-651. doi:10.1164/rccm.201001-0014OC

[57] Cargnoni, A., Gibelli, L., Tosini, A., Signoroni, P.B.,
Nassuato, C., Arienti, D., et al. (2009) Transplantation of allogeneic and xenogeneic placenta-derived cells reduces bleomycin-induced lung fibrosis. Cell Transplantation, 18, 405-422. doi:10.3727/096368909788809857

[58] Rojas, M., Xu, J., Woods, C.R., Mora, A.L., Spears, W., Roman, J., et al. (2005) Bone-marrow-derived mesenchymal stem cells in repair of the injured lung. American Journal of Respiratory Cell and Molecular Biology, 33, 145-152. doi:10.1165/rcmb.2004-03300C

[59] Moodley, Y., Atienza, D., Manuelpillai, U., Samuel, C.S., Tchongue, J., Ilancheran, S., et al. (2009) Human umbilical cord mesenchymal stem cells reduce fibrosis of bleomycin-induced lung injury. American Journal of Pathology, 175, 303-313. doi:10.2353/ajpath.2009.080629

[60] Banerjee, E.R., Laflamme, M.A., Papayannopoulou, T., Kahn, M., Murry, C.E. and Henderson Jr., W.R. (2012) Human embryonic stem cells differentiated to lung lineage-specific cells ameliorate pulmonary fibrosis in a xenograft transplant mouse model. PLoS ONE, 7, e33165. doi:10.1371/journal.pone.0033165

[61] Spitalieri, P., Quitadamo, M.C., Orlandi, A., Guerra, L., Giardina, E., Casavola, V., et al. (2012) Rescue of murine silica-induced lung injury and fibrosis by human embryonic stem cells. European Respiratory Journal, 39, 446457. doi:10.1183/09031936.00005511

[62] Hare, J.M., Traverse, J.H., Henry, T.D., Dib, N., Strumpf, R.K., Schulman, S.P., et al. (2009) A randomized, double-blind, placebo-controlled, dose-escalation study of intravenous adult human mesenchymal stem cells (prochymal) after acute myocardial infarction. Journal of the American College of Cardiology, 54, 2277-2286. doi:10.1016/j.jacc.2009.06.055

[63] Hare, J.M., Fishman, J.E., Gerstenblith, G., DiFede Velazquez, D.L., Zambrano, J.P., Suncion, V.Y., et al. (2012) Comparison of allogeneic vs autologous bone marrowderived mesenchymal stem cells delivered by transcendocardial injection in patients with ischemic cardiomyopathy: The POSEIDON randomized trial. JAMA, 308, 2369-2379. doi:10.1001/jama.2012.25321

[64] Weiss, D.J., Casaburi, R., Flannery, R., Leroux-Williams, M. and Tashkin, D.P. (2013) A placebo-controlled, randomized trial of mesenchymal stem cells in COPD. Chest, 143, 1590-1598. doi:10.1378/chest.12-2094

[65] Chaudhary, N.I., Schnapp, A. and Park, J.E. (2006) Pharmacologic differentiation of inflammation and fibrosis in the rat bleomycin model. American Journal of Respiratory and Critical Care Medicine, 173, 769-776. doi:10.1164/rccm.200505-717OC

[66] Maher, T.M. (2013) PROFILEing idiopathic pulmonary fibrosis: Rethinking biomarker discovery. European Respiratory Review, 22, 148-152. doi:10.1183/09059180.00000913

[67] Moeller, A., Ask, K., Warburton, D., Gauldie, J. and Kolb, M. (2008) The bleomycin animal model: A useful tool to investigate treatment options for idiopathic pulmonary fibrosis? The International Journal of Biochemistry \& Cell Biology, 40, 362-382. doi:10.1016/j.biocel.2007.08.011

[68] Borzone, G., Moreno, R., Urrea, R., Meneses, M., Oyar- 
zun, M. and Lisboa, C. (2000) Bleomycin-induced chronic lung damage does not resemble human idiopathic pulmonary fibrosis. American Journal of Respiratory and Critical Care Medicine, 163, 1648-1653. doi:10.1164/ajrccm.163.7.2006132

[69] Chua, F., Gauldie, J. and Laurent, G.J. (2005) Pulmonary fibrosis: Searching for model answers. American Journal of Respiratory Cell and Molecular Biology, 33, 9-13. doi:10.1165/rcmb.2005-0062TR

[70] Degryse, A.L., Tanjore, H., Xu, X.C., Polosukhin, V.V., Jones, B.R., McMahon, F.B., et al. (2010) Repetitive intratracheal bleomycin models several features of idiopathic pulmonary fibrosis. American Journal of Physiology-Lung Cellular and Molecular Physiology, 299, L442L452. doi:10.1152/ajplung.00026.2010

[71] International Society for Stem Cell Research, Guidelines for the clinical translation of stem cells. http://www.isscr.org/home/publications/ClinTransGuide

[72] Loebinger, M.R. and Janes, S.M. (2007) Stem cells for lung disease. Chest, 132, 279-285. doi:10.1378/chest.06-2751

[73] Price, A.P., England, K.A., Matson, A.M., Blazar, B.R. and Panoskaltsis-Mortari, A. (2010) Development of a decellularized lung bioreactor system for bioengineering the lung: The matrix reloaded. Tissue Engineering Part A, 16, 2581-2591. doi:10.1089/ten.tea.2009.0659

[74] Ling, L., Nurcombe, V. and Cool, S.M. (2009) Wnt signaling controls the fate of mesenchymal stem cells. Gene, 433, 1-7. doi:10.1016/j.gene.2008.12.008

[75] Walker, N., Badri, L., Wettlaufer, S., Flint, A., Sajjan, U., Krebsbach, P.H., et al. (2011) Resident tissue-specific mesenchymal progenitor cells contribute to fibrogenesis in human lung allografts. American Journal of Pathology, 178, 2461-2469. doi:10.1016/j.ajpath.2011.01.058

[76] Foronjy, R.F. and Majka, S.M. (2012) The potential for resident lung mesenchymal stem cells to promote functional tissue regeneration: Understanding microenvironmental cues. Cells, 1, 874. doi:10.3390/cells1040874

[77] Warburton, D., Perin, L., DeFilippo, R., Bellusci, S., Shi, W. and Driscoll, B. (2008) Stem/progenitor cells in lung development, injury repair, and regeneration. Proceedings of the American Thoracic Society, 5, 703-706. doi:/10.1513/pats.200801-012AW
[78] Grove, J.E., Lutzko, C., Priller, J., Henegariu, O., Theise, N.D., Kohn, D.B. et al. (2002) Marrow-derived cells as vehicles for delivery of gene therapy to pulmonary epithelium. American Journal of Respiratory Cell and Molecular Biology, 27, 645-651. doi:10.1165/rcmb.2002-0056RC

[79] Loi, R., Beckett, T., Goncz, K.K., Suratt, B.T. and Weiss, D.J. (2006) Limited restoration of cystic fibrosis lung epithelium in vivo with adult bone marrow-derived cells. American Journal of Respiratory and Critical Care Medicine, 173, 171-179. doi:10.1164/rccm.200502-309OC

[80] Aguilar, S., Scotton, C.J., McNulty, K., Nye, E., Stamp, G., Laurent, G., et al. (2009) Bone marrow stem cells expressing keratinocyte growth factor via an inducible lentivirus protects against bleomycin-induced pulmonary fibrosis. PLOS ONE, 4, e8013. doi:10.1371/journal.pone.0008013

[81] Konigshoff, M., Kramer, M., Balsara, N., Wilhelm, J., Amarie, O.V., Jahn, A., et al. (2010) WNT1-inducible signaling protein-1 mediates pulmonary fibrosis in mice and is upregulated in humans with idiopathic pulmonary fibrosis. The Journal of Clinical Investigation, 119, 772 787. doi:10.1172/JCI33950

[82] Macchiarini, P., Jungebluth, P., Go, T., Asnaghi, M.A., Rees, L.E., Cogan, T.A., et al. (2008) Clinical transplantation of a tissue-engineered airway. Lancet, 372, 20232030. doi:10.1016/S0140-6736(08)61598-6

[83] Andrade, C.F., Wong, A.P., Waddell, T.K., Keshavjee, S. and Liu, M. (2007) Cell-based tissue engineering for lung regeneration. American Journal of Physiology - Lung Cellular and Molecular Physiology, 292, 510-518. doi:10.1152/ajplung.00175.2006

[84] Yu, W., Fang, X., Ewald, A., Wong, K., Hunt, C.A., Werb, Z., et al. (2007) Formation of cysts by alveolar type II cells in three-dimensional culture reveals a novel mechanism for epithelial morphogenesis. Molecular Biology of the Cell, 18, 1693-1700. doi:10.1091/mbc.E06-11-1052

[85] Nichols, J.E. and Cortiella, J. (2008) Engineering of a complex organ: Progress toward development of a tissueengineered lung. Proceedings of the American Thoracic Society, 5, 723-730. doi:10.1513/pats.200802-022AW 